\title{
AMBLING IN THE ARCTIC: THE SKAERGAARD INTRUSION
}

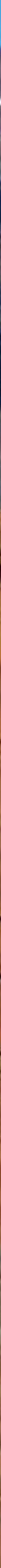




\section{Victoria Honour relays tales of Arctic foxes, narwhals and the Aurora Borealis during fieldwork mapping of the Skaergaard Intrusion, south-east Greenland}

W

ith a population of only 70,000 , and a landmass nine times the size of the UK, Greenland remains relatively untouched by

human activity. Fieldwork there can be a blissful escape from the $24 / 7$ connectivity of everyday life, and I was very lucky to be given such an opportunity.

My Ph.D. research addresses the physical behaviour of emulsions - mixtures of immiscible liquids — in porous media. Emulsions are widely studied in the petroleum industry and are of great importance for carbon sequestration and food processing, yet little is known about the physical behaviour of emulsions during the evolution of large bodies of molten rock trapped beneath Earth's surface.

Recently, it was shown that basaltic magma may split into two immiscible liquids, one silica-rich and the other ironrich, during fractionation. The physical properties of the two immiscible liquids are very different, with the silica-rich magma being highly viscous and buoyant compared to its iron-rich conjugate. Furthermore, elements of economic interest, such as gold and platinum-group elements, preferentially associate with the iron-rich conjugate. The chemical evolution of magma and the formation of economic ore deposits are strongly influenced by large-scale mass transport within mush zones in the crust, so we really do need to understand how an unmixed interstitial liquid might behave. One component of my research is an examination of natural examples of gabbroic rocks in which liquid immiscibility played an important role during fractionation: Skaergaard is such an example.

\section{Why Skaergaard?}

The Skaergaard Intrusion, on the coast of East Greenland at $68^{\circ} \mathrm{N}$, is a $10-\mathrm{km}$ scale body of basaltic magma. It formed around 55 million years ago when magma, destined to be one of the many large flood basalt flows that erupted during the opening of the Atlantic Ocean, failed to reach the surface. Instead, the magma became trapped in the crust and solidified without interruption. Surface uplift associated with the Iceland plume (the cause of the huge amounts of mantle melting, and perhaps the underlying trigger for the opening of the North Atlantic Ocean) means that the Skaergaard Intrusion is today exposed at the surface. The excellent exposure of this example of extreme basaltic fractionation makes it one of the best places in the world to study crystallisation processes. This natural laboratory was discovered by Lawrence Wager in 1930 during an expedition aimed at mapping out an air route across Greenland. Since then, studies of Skaergaard have helped progress many fundamental ideas in igneous petrology.

\section{Mapping melt}

I was part of a team of six geologists, who spent four weeks exploring the intrusion and collecting data for a range of scientific projects. The other team members comprised Sam Weatherley from the Geological Survey of Denmark and Greenland, Jens Andersen from the University of Exeter, Marian Holness and Gautier Nicoli from the University of Cambridge, and Brendan Dyck, formerly at Cambridge and now at Simon Fraser University, Canada.

We went out to Skaergaard with a large number of scientific aims that we were hoping to address. My main aim was to map late-stage melt structures across the intrusion and document field-scale evidence of differential migration of immiscible liquids. The month-long field trip was extremely conducive to group reflection and discussion. It meant that hypotheses developed at the outcrop could be discussed and refined in the evenings, with the opportunity to return and test those ideas the next day. 

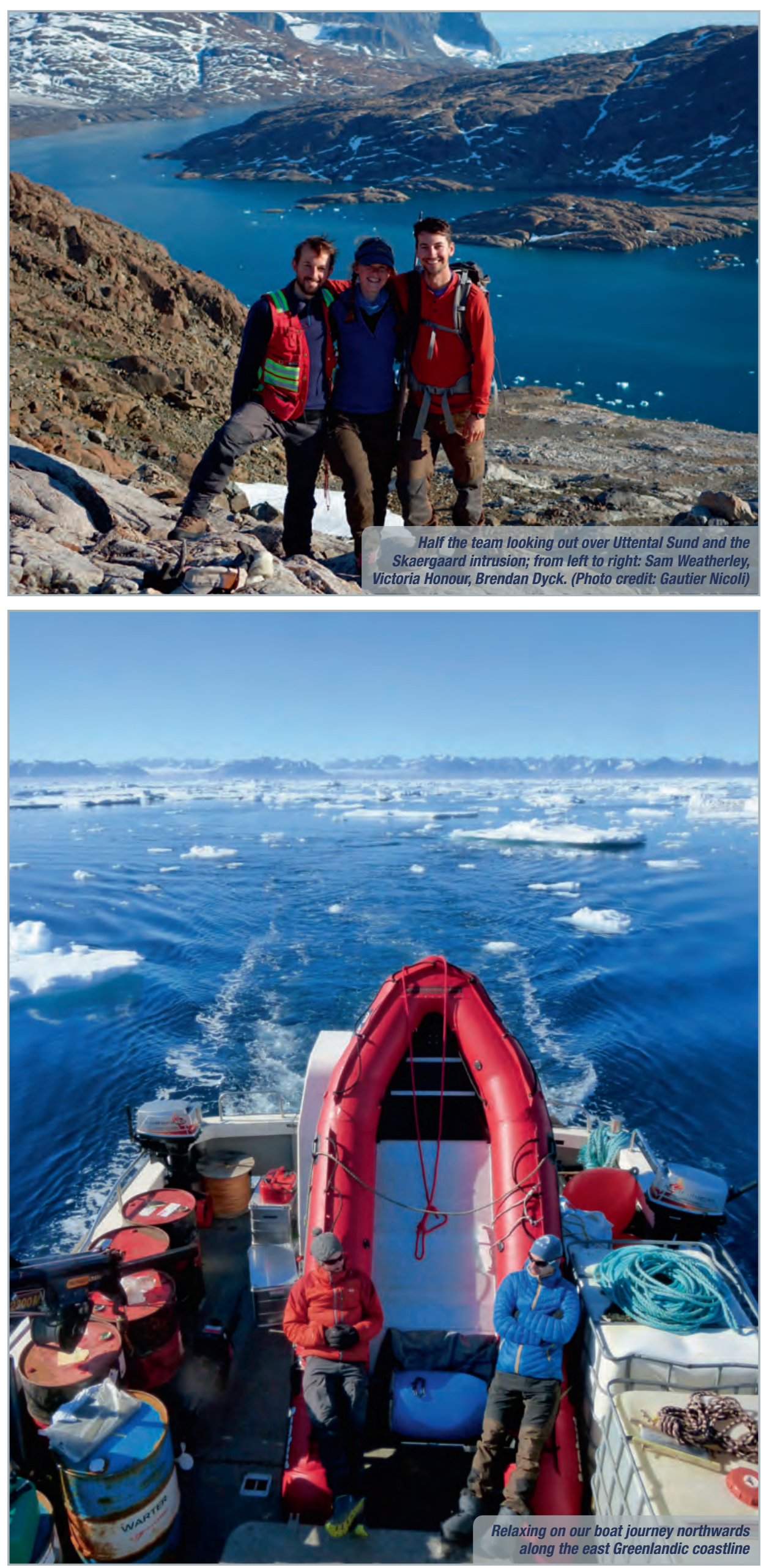

\section{Careful observations}

My primary focus was making careful observations of the geometry of latestage liquid segregations, to deduce the permeability of the crystal mush and to see if there were any patterns in this behaviour. With a combination of detailed mapping, small-scale observations and photography, I built a comprehensive field data-set of different features that we could link with the architecture of the solidifying crystal mush.

We looked at beautiful 'Christmas tree' dendritic structures that formed by the squirting of liquid along strongly foliated layers in an otherwise impermeable mush (just like those formed in a Hele-Shaw cell) and contrasted these with blobby pegmatitic bodies that form in unlayered and highly permeable mush. We also found many examples of pod-like accumulations of liquid in which the iron-rich and silica-rich conjugates had separated to form stark black and white divisions. Sampling was sometimes challenging because the crystals in the coarse-grained pegmatites crumbled easily, but with a lot of perseverance I collected enough samples suitable for thin sectioning (albeit still requiring a lot of epoxy impregnation!).

\section{The expedition}

Getting to East Greenland is surprisingly easy...with commercial flights from London Heathrow to Iceland and then on to Kulusuk airport in Greenland. From Kulusuk we charted a local boat, which took us $150 \mathrm{~km}$ north to Skaergaard and gave us a chance to acclimatise to the Arctic. We sailed past an abandoned World War II US coastal airstrip, complete with hundreds of disintegrating, rusty oil drums, and a humpback whale sunbathing just offshore. We also had to spend considerable time navigating through large areas of densely packed sea-ice. We reached Skaergaard in glorious sunshine, getting our first look at Wager's Peak, which dominates the skyline.

Fieldwork in such an environment is always a delicate balance between 'science time' and 'camp time'. The first couple of days saw us settle into our daily routine and adjust to about 19 hours of daylight. We got used to our daily commute in the field: a boat ride wearing lurid orange 
survival suits, followed by a hike across the intrusion. The Arctic scenery is stunning, but it is a harsh, unforgiving landscape. There is minimal vegetation giving near $100 \%$ rock exposure-excellent for geology, but providing a colour palette restricted to whites, browns and greys, from the snow, rock and sea. That is, until our penultimate night when the Northern Lights finally put on a colourful display.

Skaergaard has a favourable microclimate, attracting an abundance of narwhals and seals. Our fieldwork was largely uninterrupted by the local wildlife, although on one memorable morning we spotted a magnificent polar bear swimming in the fjord. We were paid regular visits by two rather poorly-behaved Arctic foxes who had a habit of chewing through socks; they relished ropes too - particularly those holding up tents and anchoring the boats. We were also paid some interesting visits by local hunters, Swiss tourists on a sailing trip, and a group of marine biologists tagging narwhals.

Working and living as part of a small team is an intense, but incredibly rewarding experience. Our departure from Greenland in the beautiful sunshine was bittersweet. While running water, fresh food and a bed beckoned, the magical wilderness of Greenland is hard to walk away from. It is a truly spectacular environment and it was a privilege to have visited and worked in such a special place. I owe many thanks to the Annie Greenly Fund from the Geological Society of London for supporting me and enabling me to join such a wonderful expedition.
Victoria Honour is in the

Department of Earth Sciences, University of Cambridge, UK, and was a 2017 recipient of the Geological Society of London's Annie Greenly Fund (email: vch28@cam.ac.uk; twitter: @victoria_honour).
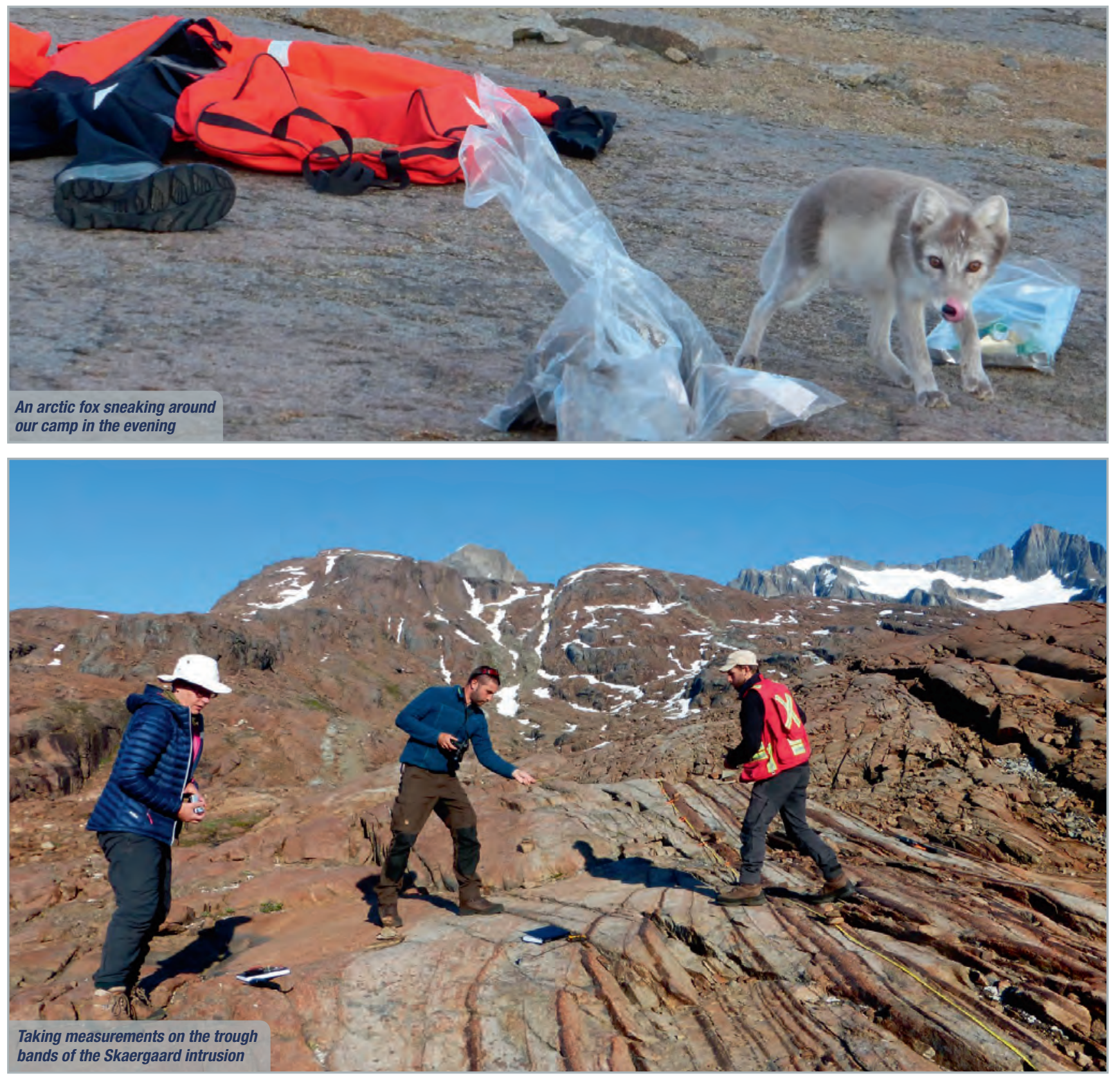